\title{
Pelatihan Rich Task Pada Mgmp Matematika SMP Lombok Barat
}

\author{
Ita Chairun Nissa1, I Ketut Sukarma ${ }^{2}$, Sanapiah $^{3}$, Ade Kurniawan ${ }^{4}, \operatorname{Sabrun}^{5}$ \\ Prodi Pendidikan Matematika, Universitas Pendidikan Mandalika-NTB-Indonesia \\ Email Korespondensi: itachairunnissa@ikipmataram.ac.id
}

\begin{abstract}
The West Lombok Mathematics' Teacher Community needs to be improved because of the government's demands on the quality of teaching mathematics in schools. Having good mathematical knowledge and being able to solve real-life problems is an important key for teachers to be able to develop innovative mathematics teaching. But in fact, teacher training that emphasizes aspects of mathematical content is still not widely implemented. This is an important reason for this training. The training is carried out in one day through video screening and rich task modeling. The assessment of this training is measured using a closed questionnaire that asks the teacher's attitude towards statements related to the training material, training methods, the ability of the speakers, and the motivation of the trainees. The training that was carried out succeeded in getting a positive response that most of the teachers gave a very agreeing attitude. The teachers also feel motivated and have good expectations for applying the knowledge and skills gained from training into teaching mathematics in the classroom
\end{abstract}

Keywords. Teacher Training;Rich Task;Mathematics’ Teacher Community.

Abstrak. MGMP Matematika wilayah Lombok Barat perlu untuk ditingkatkan karena tuntutan pemerintah terhadap kualitas pengajaran matematika di sekolah. Memiliki pengetahuan matematika yang bagus dan mampu memecahkan masalah kehidupan nyata adalah kunci penting bagi guru untuk dapat mengembangkan pengajaran matematika yang inovatif. Namun faktanya, pelatihan guru yang menekankan pada aspek konten matematika masih belum banyak dilaksanakan. Hal inilah yang menjadi alasan penting dilakukannya pelatihan ini. Pelatihan dilaksanakan dalam satu hari melalui pemutaran video dan pemodelan rich task. Penilaian terhadap pelatihan ini diukur menggunakan angket tertutup yang meminta sikap guru atas pernyataan-pernyatan terkait materi pelatihan, metode pelatihan, kemampuan pemateri, dan motivasi peserta pelatihan. Pelatihan yang telah dilakukan berhasil mendapatkan respon positif yaitu sebagian besar guru memberikan sikap sangat setuju. Para guru juga merasa termotivasi dan memiliki harapan yang baik untuk menerapkan pengetahuan dan keterampilan yang diperoleh dari pelatihan ke dalam pengajaran matematika di kelas.

Kata Kunci. Pelatihan Guru; Rich Task; MGMP Matematika.

\section{PENDAHULUAN}

Undang-undang Republik Indonesia Nomor 14 Tahun 2005 tentang Guru dan Dosen, Peraturan Pemerintah Nomor 19 Tahun 2005 tentang Standar Nasional Pendidikan, dan Peraturan Pemerintah Nomor 74 Tahun 2008 tentang Guru mengamanatkan bahwa sesuai dengan perkembangan ilmu pengetahuan, teknologi, dan seni maka guru harus meningkatkan kompetensinya secara berkelanjutan. Sehubungan dengan hal tersebut, agar proses peningkatan kualifikasi akademik dan kompetensi guru terprogram serta terlaksana dengan baik maka diperlukan wadah pembinaan guru yang mandiri dan professional. Wadah pembinaan guru yang sudah ada yaitu Kelompok Kerja Guru (KKG) untuk guru SD/MI/SDLB dan Musyawarah Guru Mata Pelajaran (MGMP) untuk guru SMP/MTs/SMPLB, SMA/MA/SMALB, dan SMK/MAK. Namun wadah pembinaan guru tersebut saat ini masih belum berjalan dengan baik dan banyak menghadapi berbagai kendala (Kemdiknas, 2010). Menurut laporan ketua MGMP Matematika SMP wilayah Lombok Barat, diketahui bahwa kegiatan MGMP yang dilaksanakan selama ini masih belum optimal karena tidak semua guru mau 
memanfaatkan kegiatan MGMP sebagai wadah untuk meningkatkan kompetensinya. Permasalahan lain yang selalu timbul dan merupakan masalah klasik selama ini adalah minimnya dana untuk melaksanakan kegiatan MGMP secara rutin. Disamping permasalahan dana, pola-pola kegiatan MGMP yang dilaksanakan selama ini belum mampu meningkatkan kompetensi dan profesionalisme kerja guru. Namun ditengah keterbatasan dan masalah yang dihadapi oleh MGMP Matematika SMP Lombok Barat, mereka tetap memiliki tekad yang kuat untuk meningkatkan kompetensi guru yang menjadi anggotanya agar para guru memiliki kompetensi profesional yang memadai dan mampu bekerja secara optimal sehingga dapat meningkatkan prestasi belajar siswanya (Nursahid, 2012).

Materi pelatihan yang disampaikan kepada guru dalam kegiatan MGMP perlu mendapatkan perhatian yang serius karena dapat mempengaruhi tingkat partisipasi peserta dan peningkatan kompetensinya. Beberapa guru peserta MGMP Matematika SMP Lombok Barat yang pernah mengikuti beberapa pelatihan menyatakan bahwa materi pelatihan yang kaya terhadap konten matematika lebih memotivasi dan bermanfaat bagi guru daripada materi pelatihan mengenai pedagogi atau kebijakan kurikulum semata. Para guru merasakan dampak langsung meningkatnya kemampuan mengajar karena materi yang diperoleh dirasakan sangat bermanfaat (Zulkifli, 2017). Pengalaman yang dirasakan guru MGMP memang beralasan karena secara teoritis pembelajaran matematika menekankan pada pemberian pengalaman langsung untuk mengembangkan kompetensi siswa. Pembelajaran matematika sebaiknya diarahkan untuk mencari tahu dan bertindak sehingga dapat membantu siswa untuk memperoleh pemahaman konsep yang diinginkan (Marzuki et al., 2019).

Beberapa pelatihan yang pernah diperoleh guru peserta MGMP Matematika SMP wilayah Lombok Barat dalam tiga tahun terakhir antara lain (1) Pelatihan pembuatan media pembelajaran matematika (Zulkifli, 2017); (2) Pelatihan software matematika Geogebra, Maple, QM for Windows, Delphi
Math, dan Matlab (Abdillah et al., 2018); dan (3) Pelatihan pemahaman konsep dasar matematika (Marzuki et al., 2019). Berdasarkan beberapa pelatihan itu nampak bahwa MGMP Matematika SMP wilayah Lombok Barat belum pernah mendapatkan pelatihan mengenai masalah matematika berbobot (rich task), padahal materi pelatihan ini sangat diperlukan oleh guru mata pelajaran matematika karena sangat terkait langsung dengan praktik pengajaran di kelas. Oleh karena itu, sangat perlu untuk memberikan pelatihan tentang masalah matematika berbobot (rich task) kepada guru peserta MGMP Matematika SMP wilayah Lombok Barat. Rich task dapat diartikan sebagai suatu bentuk tugas yang bersifat open-ended yang mampu melibatkan siswa dalam mengkoneksikan matematika di sekolah ke konteks kehidupan nyata (Moulds, 2004). Suatu kelas yang didalamnya terdapat aktivitas rich task akan memiliki kualitas akademik yang baik, mampu mengembangkan kemampuan matematika yang kuat dan menumbuhkan sikap positif, partisipasi dan keterlibatan secara matematika. Suatu masalah matematika dapat dikatakan sebagai masalah matematika berbobot (rich task) apabila memenuhi unsurunsur seperti; (1) Memunculkan multirepresentasional terhadap jalur pemecahan dan solusi; (2) Membutuhkan sumber daya bersama kolektif; dan (3) Memiliki keterhubungan antara konsep dan ide matematika dengan bidang disiplin lain dan persoalan kehidupan nyata (Grootenboer, 2009).

Pelatihan ini dilaksanakan di SMP Negeri 1 Kediri, Kabupaten Lombok Barat, NTB, Indonesia. Lokasi ini merupakan sekretariat MGMP Matematika SMP untuk wilayah Lombok Barat bagian selatan. Tujuan yang ingin dicapai dari pelatihan ini adalah memberikan pengetahuan baru kepada guru tentang masalah matematika berbobot (rich task), memberikan keterampilan kepada guru dalam memodelkan masalah matematika berbobot (rich task), serta menumbuhkan motivasi dan keterlibatan guru dalam aktivitas MGMP Matematika. Keberhasilan pelatihan ini diharapkan dapat memberikan manfaat 
bagi upaya peningkatan kualitas partisipasi, keterlibatan, dan materi kegiatan MGMP sehingga semua guru matematika dapat saling berbagi pengetahuan dan belajar keterampilan secara kolaboratif. Pelatihan ini terlaksana berkat dukungan dari berbagai pihak antara lain Ketua MGMP Matematika SMP wilayah Lombok Barat sebagai tuan rumah penyelenggara pelatihan, GPFD Project ELPSA Framework yang memfasilitasi materi, transportasi, dan akses ke MGMP, dan LPMP NTB yang memberikan dukungan moril sekaligus memantau proses pelatihan.

\section{METODE PENELITIAN}

Pelatihan ini dilaksanakan di SMP Negeri 1 Kediri, Lombok Barat, NTB sebagai sekretariat MGMP Matematika SMP wilayah Lombok Barat. Jumlah peserta pelatihan sebanyak 20 guru matematika yang berasal dari SMP Negeri 1 Kediri, SMP Negeri 2 Kediri, SMP Negeri 3 Kuripan, SMP Negeri 2 Labuapi, SMP Negeri 3 Labuapi dan SMP Negeri Satu Atap 2 Kediri. Pelatihan ini merupakan one-day training yang dilaksanakan dengan metode pemutaran video dan pemodelan (modeling). Metode pemutaran video telah direkomendasikan untuk pelatihan peningkatan kompetensi guru (Purnomo \& Wijayanto, 2018). Melalui pemutaran video, guru dapat meningkatkan retensi pengetahuan dan sikapnya (Wibawa, 2007). Menggunakan pemutaran video juga dapat membuat penggunaan waktu pelatihan menjadi lebih efisien. Selanjutnya, metode kedua yang digunakan dalam pelatihan ini adalah pemodelan (modeling). Pemodelan bertujuan untuk memberikan keterampilan dalam menerapkan konsep masalah matematika berbobot (rich rask) yang telah diperoleh pada sesi pemutaran video. Melalui praktik langsung, peserta dapat belajar bagaimana mengkoneksikan pengetahuan baru ke dalam pemecahan masalah. Jadi pemodelan melibatkan proses kognitif sehingga peserta pelatihan tidak hanya sekedar meniru apa yang telah diamati dalam video tetapi dapat merepresentasi informasi secara simbolis dan menyimpannya untuk digunakan di masa depan (Khafidhoh et al., 2015). Pada akhir pelatihan ini seluruh peserta diberikan angket sebagai bahan refleksi atas keterlaksanaan pelatihan. Angket dibuat dalam bentuk tertutup yang bertujuan untuk mengukur sikap peserta pelatihan dalam beberapa pernyataan yang diajukan. Tingkat sikap setuju peserta dinilai dengan skala Likert dengan kriteria antara lain "SS" untuk sikap "Sangat Setuju", "S" untuk sikap "Setuju", "CS" untuk sikap "Cukup Setuju", "KS" untuk sikap "Kurang Setuju", dan "TS" untuk sikap "Tidak Setuju" (Retnawati, 2015). Data skor angket kemudian dikonversi dalam bentuk persentase untuk dicocokkan dengan kriteria pada Tabel 1 (Sartika, 2017).

Tabel 1. Kriteria Penilaian

\begin{tabular}{|c|c|}
\hline Persentase Skor & Kriteria \\
\hline $0 \%$ & Tidak ada/Tidak seorang pun \\
\hline $1 \%-24 \%$ & Sebagian kecil \\
\hline $25 \%-49 \%$ & Kurang dari setengahnya \\
\hline $50 \%$ & Setengahnya \\
\hline $51 \%-74 \%$ & Lebih dari setengahnya \\
\hline $75 \%-99 \%$ & Sebagian besar \\
\hline $100 \%$ & Seluruhnya \\
\hline
\end{tabular}

Keberhasilan keterlaksanaan pelatihan ini dicapai apabila minimal memberikan sikap "Setuju" dengan kriteria "Sebagian Besar". Hal ini diartikan bahwa guru peserta MGMP Matematika SMP wilayah Lombok Barat memberikan respon yang positif terhadap materi pelatihan, metode pelatihan, kemampuan pemateri dalam memberikan pelatihan serta motivasi dan harapan peserta terhadap keberlanjutan pelatihan

\section{HASIL DAN PEMBAHASAN}

Kegiatan pelatihan ini dimulai dengan melakukan presentasi mengenai teori pembelajaran matematika yang menekankan pada pentingnya aspek aplikasi dari konsep matematika yang telah dipelajari di kelas. Mengaplikasikan konsep matematika dapat dipraktekkan melalui masalah matematika berbobot (rich task). Mengajarkan masalah matematika berbobot (rich task) lebih efektif apabila disampaikan melalui contoh langsung secara nyata karena dapat memudahkan guru untuk menangkap informasi yang ingin disampaikan. Selain itu, cara ini dapat membuat penggunaan waktu pelatihan menjadi lebih efisien. Peserta pelatihan diminta untuk menonton suatu video yang 
menceritakan mengenai suatu aktivitas membentuk prisma dari empat kartu remi yang berukuran sama tetapi dengan arah menyusun kartu yang berbeda yaitu horizontal dan vertikal. Perbedaan arah menyusun kartu untuk dibentuk menjadi prisma tersebut ternyata menghasilkan dua prisma dalam bentuk yang berbeda, padahal dua prisma ini tersusun dari kartu remi yang berukuran sama. Berdasarkan kasus ini, peserta pelatihan diminta untuk memikirkan apakah dua prisma tersebut memiliki volume yang sama atau tidak. Pengajuan kasus seperti ini kepada peserta pelatihan merupakan awal yang baik untuk membangkitkan keingintahuan peserta terhadap masalah matematika berbobot (rich task). Deskripsi berikut ini menjelaskan bagaimana proses aktivitas menonton video terjadi dan bagaimana peserta pelatihan berupaya untuk memecahkan kasus tersebut.

\section{Aktivitas 1: Mengamati Video ke-1}

Video ini mendeskripsikan tentang aktivitas membentuk dua prisma berbeda yang masing-masing terbentuk dari empat kartu remi dengan ukuran yang sama.

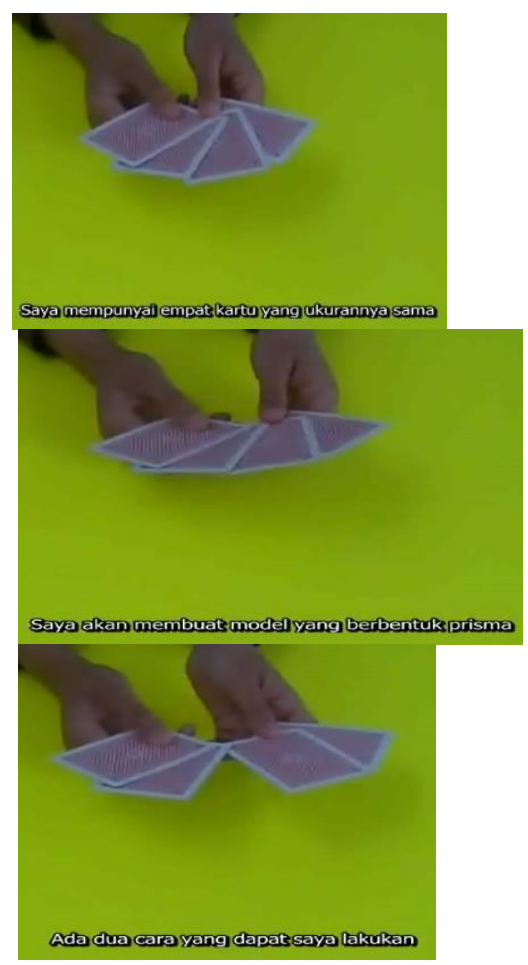

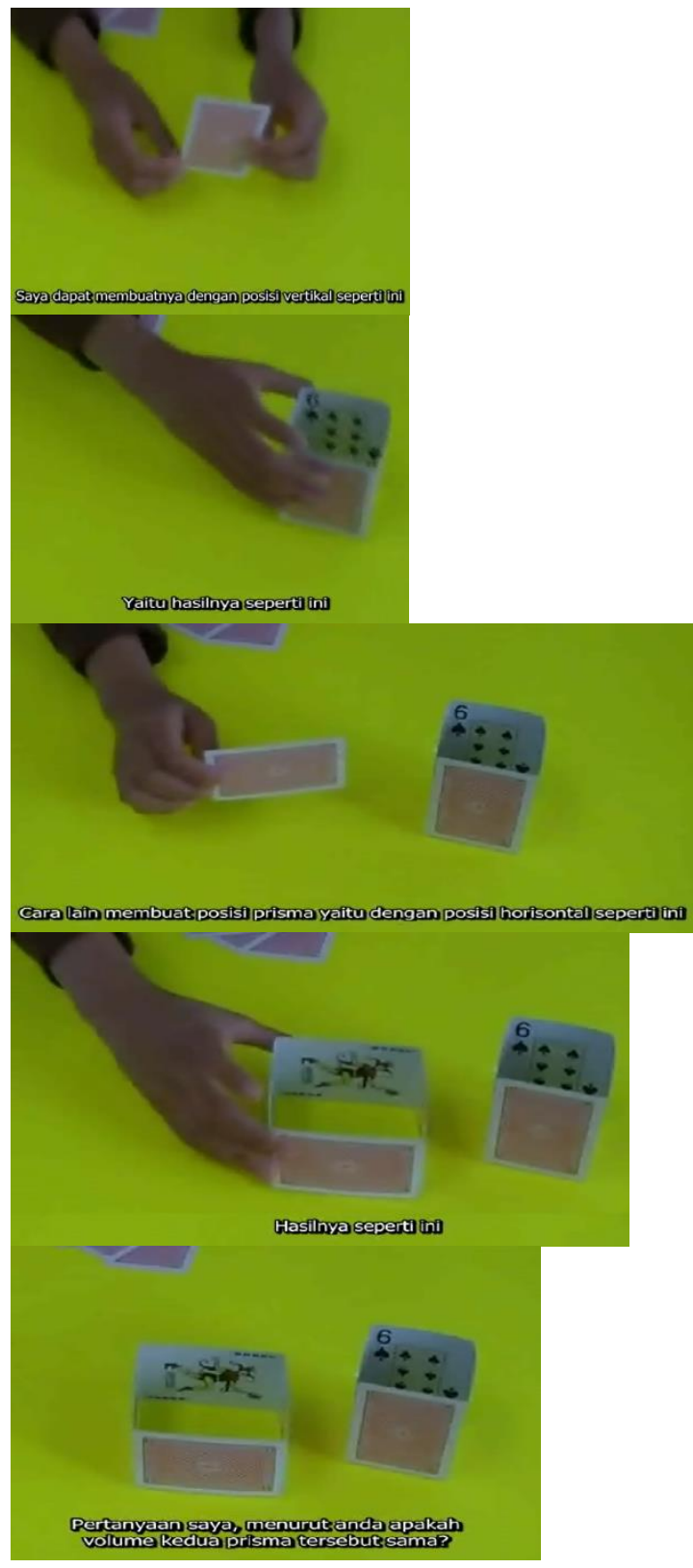

Gambar 1. Video ke-1 Mathematical Rich Task (sumber: GPFD Project ELPSA Framework)

Peserta pelatihan diberikan waktu selama kurang lebih lima menit untuk mencoba memikirkan jawaban dari pertanyaan yang diajukan. Semua peserta sangat antusias untuk mencoba menjawab. Ada peserta yang menghitung volume kedua prisma dengan memisalkan ukuran panjang, lebar dan tinggi prisma dengan suatu variabel tak diketahui dan kemudian membandingkannya. Ada juga peserta yang meminta untuk mengulang kembali video tersebut agar mereka mendapatkan gambaran secara mental mengenai besaran volume 
kedua prisma tersebut. Bagian yang paling menarik pada tahap ini adalah seperti apa jawaban peserta pelatihan terhadap kasus tersebut. Ternyata hasilnya adalah sebagian besar peserta pelatihan menjawab bahwa volume kedua prisma adalah sama karena keduanya dibuat dari empat kartu remi yang berukuran sama. Jawaban peserta pelatihan ini tentunya sangat menarik untuk ditindaklanjuti dengan aktivitas menonton video selanjutnya.

\section{Aktivitas 2: Mengamati Video ke-2}

Video ini mendeskripsikan tentang suatu cara sederhana untuk membuktikan apakah volume dua prisma yang berbeda adalah sama atau tidak.

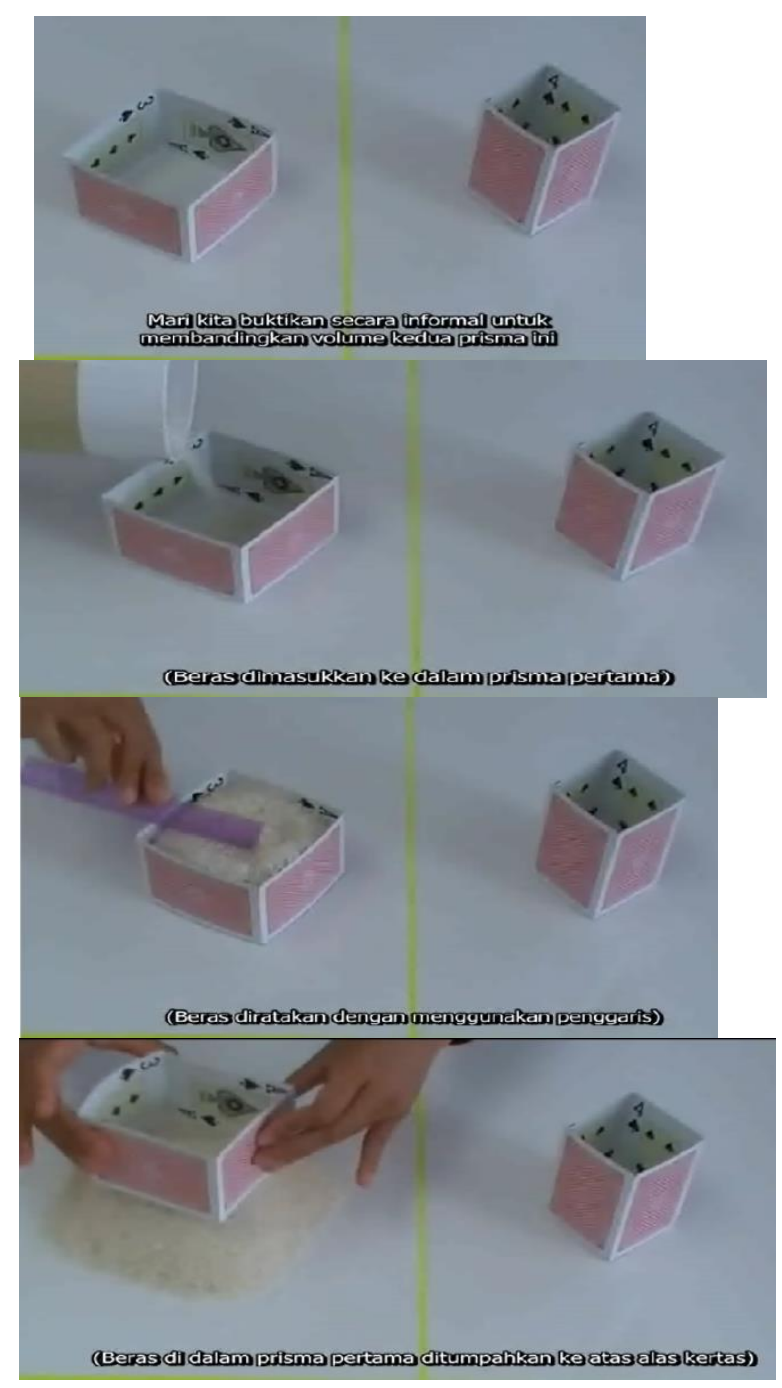

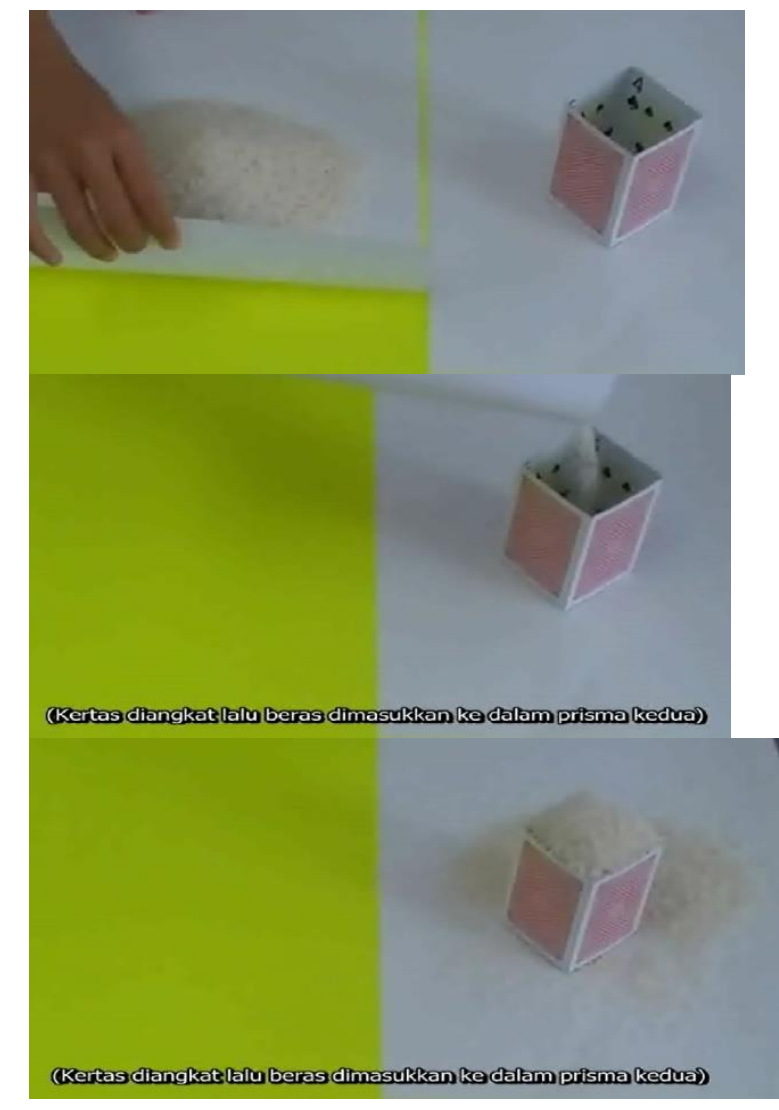

Gambar 2. Video ke-2 Mathematical Rich Task (sumber: GPFD Project ELPSA Framework)

Melalui pemutaran video ke-2 dapat diketahui bahwa volume prisma pertama lebih besar daripada volume prisma kedua. Jawaban ini di luar dugaan peserta pelatihan karena sebagian besar dari mereka menjawab bahwa volume kedua prisma adalah sama karena dibuat dari empat kartu yang berukuran sama. Kasus ini memberikan pengetahuan kepada peserta pelatihan bahwa luas permukaan suatu bangun ruang berbanding lurus dengan volumenya. Semakin besar luas permukaan suatu bangun ruang maka semakin besar pula volumenya, demikian juga sebaliknya. Luas permukaan prisma pertama lebih besar daripada luas permukaan prisma kedua karena prisma pertama dibuat dari kartu remi dengan arah horizontal, dan sebaliknya prisma pertama dibuat dengan arah vertikal. Setelah peserta pelatihan menonton video yang kedua, diharapkan mereka akan mendapatkan wawasan dan pengalaman langsung sebagai subjek yang diberikan masalah matematika yang berbobot (rich task). Dengan cara seperti ini, para guru peserta pelatihan dapat 
termotivasi untuk melakukan aktivitas yang serupa kepada siswanya di kelas.

\section{Aktivitas 3: Pemodelan Rich Task}

Aktivitas ini merupakan suatu praktik nyata untuk menerapkan secara langsung konsep "hubungan linier antara luas permukaan dan volume bangun ruang" yang telah dipelajari pada aktivitas menonton video. Peserta pelatihan dibagi dalam kelompok kecil untuk merancang suatu model kapal laut yang memiliki volume dan kapasitas terbesar. Berikut ini aturan yang diberikan kepada peserta:

1. Peserta bekerja dalam kelompok dan harus aktif terlibat dalam setiap pekerjaan.

2. Setiap kelompok akan diberikan selembar plastik mika berukuran $15 \mathrm{~cm}$ x $15 \mathrm{~cm}$ untuk dibuat model kapal laut apa saja yang memiliki volume dan kapasitas terbesar. Setiap model kapal laut yang berhasil dibuat kemudian harus dihitung volumenya.

3. Pengujian terhadap kapasitas dari model kapal laut dilakukan dengan cara meletakkan kapal laut di atas air dalam wadah yang telah disediakan. Sedikit demi sedikit dituangkan beras di atasnya hingga mencapai kapasitas terbesarnya yang ditandai dengan tidak tenggelamnya kapal tersebut. Beras kemudian dipindahkan ke gelas ukur untuk ditentukan beratnya.

4. Data mengenai volume model kapal laut dan berat beras yang berhasil dimuat oleh model kapal laut dituliskan di papan tulis, kemudian dibandingkan antara kelompok yang satu dengan kelompok lainnya. Kelompok yang berhasil memiliki volume dan kapastitas terbesar dari model kapal lautnya adalah pemenangnya.

Berikut ini adalah dokumentasi kegiatan kelompok pada saat merancang model kapal laut.

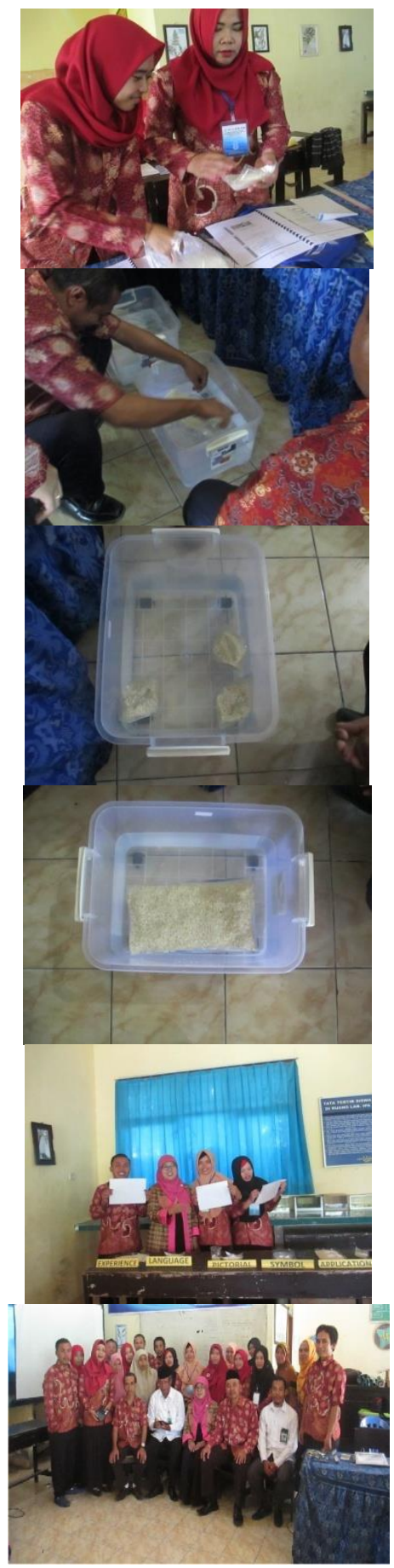

Gambar 3 Aktivitas Pemodelan Rich Task dan Sesi Foto Bersama

Terdapat lima model kapal laut yang berhasil dibuat oleh lima kelompok yaitu; (1) kelompok Experience, (2) kelompok Language, (3) kelompok Pictorial, (4) kelompok Symbolic, dan (5) kelompok Application. Nama-nama kelompok ini berdasarkan teori ELPSA framework yang mendasari konsep masalah matematika berbobot (rich task) khususnya pada 
komponen A yaitu Application (Nissa et al., 2018). Berdasarkan hasil pengujian kapasitas kapal laut di atas air, diketahui bahwa dua dari lima model kapal laut tersebut berhasil memiliki volume dan kapasitas terbesar. Dua model kapal laut itu adalah rancangan dari kelompok Experience dan kelompok Application. Dua kelompok tersebut berhasil menerapkan konsep "hubungan linier antara luas permukaan dan volume bangun ruang". Peserta dari kedua kelompok tersebut membuat model kapal laut yang menyerupai bangun ruang balok dengan alas yang lebih luas. Plastik mika dibentuk menjadi bangun ruang balok sedemikian rupa sehingga memiliki ukuran panjang dan lebar yang lebih besar daripada ukuran tingginya. Model kapal laut seperti ini mampu memuat beras lebih banyak daripada model kapal laut lainnya.

\section{Aktivitas 4: Refleksi}

Aktivitas ini bertujuan untuk mengetahui respon peserta terhadap pelatihan yang telah dilaksanakan. Setiap peserta diberikan angket tertutup yang memuat sejumlah pertanyaan. Setiap peserta mengisi angket tanpa memberikan identitas pribadi agar penilaian terhadap keterlaksanaan pelatihan menjadi lebih objektif. Data hasil angket keterlaksanaan pelatihan dapat dilihat pada Tabel 2.

Tabel 2. Data Angket Respon Peserta Terhadap Keterlaksanaan Pelatihan

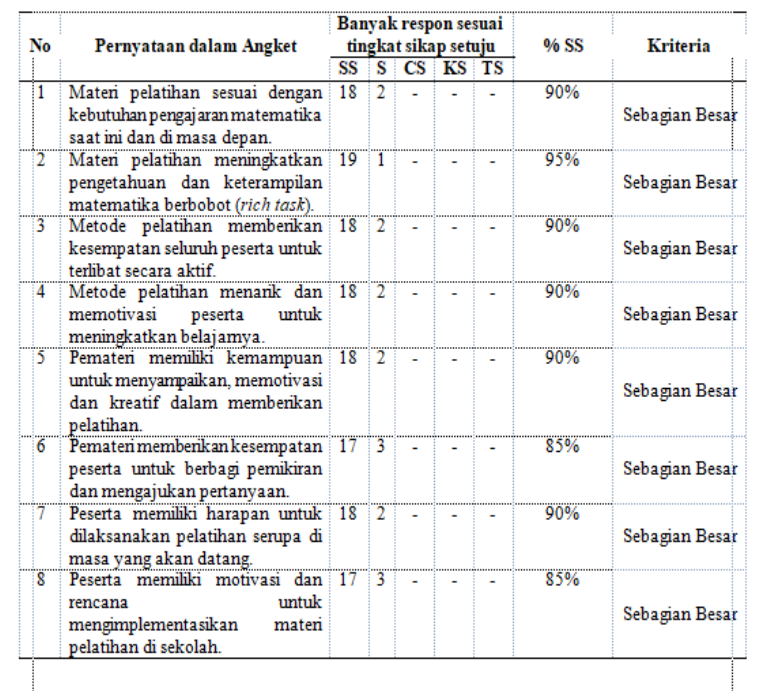

Berdasarkan data angket respon peserta pelatihan diketahui bahwa sebagian besar guru peserta MGMP Matematika SMP wilayah Lombok Barat memberikan sikap sangat setuju terhadap semua proses pelatihan yang telah dilaksanakan. Peserta merasakan manfaat pengetahuan dan keterampilan yang diperoleh melalui pelatihan ini, membangkitkan semangat dan motivasi belajar matematika serta memiliki harapan dan rencana untuk mengimplementasikannya di kelas. Jadi secara keseluruhan, pelatihan ini dapat dikatakan telah berhasil meningkatkan pengetahuan, keterampilan dan motivasi guru matematika SMP di wilayah Lombok Barat. Hasil pelatihan ini sejalan dengan Suarja et al (2017) yang menyatakan bahwa program pelatihan guru dalam MGMP Matematika dapat dijadikan sebagai salah satu wadah yang dapat digunakan untuk mengajarkan guru tentang pendekatan rich task. MGMP memegang peranan penting dalam pengembangan kompetensi pedagogik guru. Kompetensi pedagogik guru akan menentukan kualitas pembelajaran matematika yang akan mempengaruhi motivasi dan keterlibatan matematika siswa (Supriyanto, 2019).

\section{KESIMPULAN}

Pelatihan Guru MGMP Matematika SMP wilayah Lombok Barat telah dilaksanakan dengan baik. Guru peserta pelatihan mendapatkan pengetahuan baru yang bermakna yaitu masalah matematika berbobot (rich task). Selain itu, guru juga mendapatkan keterampilan untuk menerapkan pengetahuan mengenai rich task dalam bentuk pemecahan masalah dalam kehidupan nyata dan menumbuhkan semangat serta motivasi untuk mengembangkan matematika dan pengajarannya di sekolah. Hasil penyebaran angket menunjukkan respon yang positif dari guru peserta pelatihan yang berada pada kriteria penilaian " sebagian besar" guru memberikan sikap setuju terhadap kualitas materi dan metode pelatihan, kemampuan pemateri, dan keberlanjutan pelatihan.

\section{SARAN}

Proses dan hasil pengabdian kepada masyarakat ini dapat dijadikan acuan dalam kegiatan pelatihan sejenis untuk meningkatkan kompetensi guru dalam merancang masalah matematika berbobot 
(rich task) sebagai sarana pembelajaran matematika yang menekankan pada aspek membangun pemahaman konsep matematika secara heuristik. Hasil kegiatan ini masih perlu ditindaklanjuti dalam bentuk pendampingan secara kontinu sehingga mampu memberikan dampak positif bagi peningkatan kualitas pembelajaran matematika yang berkelanjutan.

\section{DAFTAR PUSTAKA}

Abdillah, A., Pramita, D., \& Habib, R. P. N. (2018). Peningkatan Global Media and Information Literacy Professional Network (GMILPN) MGMP Matematika di NTB. JPMB: Jurnal Pemberdayaan Masyarakat Berkarakter, 1(1), 1-9.

Grootenboer, P. (2009). Rich Mathematical Tasks in the Maths in the kimberley (MITK) Project. Crossing Divides: Proceedings of the 32nd Annual Conference of the Mathematics Education Research Group of Australasia, 1(March).

Kemdiknas, D. P. M. P. dan T. K. (2010). Prosedur Operasional Standar Penyelenggaraan KKG dan MGMP. Jakarta: Kementerian Pendidikan Nasional.

Khafidhoh, I., Purwanto, E., \& Awalya. (2015). Pengembangan Model Bimbingan Kelompok dengan Teknik Modeling untuk Meningkatkan Self-Regulated Learning pada Siswa SMPN 13 Semarang. Jurnal Bimbingan Konseling, 4(2), 92-99.

Marzuki, Sudiarta, I. W., Handayana, I. G. N. Y., Hiden, \& Qomariyah, N. (2019). Pendampingan Kegiatan Pendalaman Konsep-konsep Dasar Fisika dan Matematika bagi Guru-Guru Anggota MGMP. SELAPARANG: Jurnal Pengabdian Masyarakat Berkemajuan, 3(1), 134-138. Doi: 10.31764/jpmb.v3i1.1279.

Moulds, P. (2004). Rich-tasks. In Educational Leadership (pp. 75-778).

Nissa, I. C., Sanapiah, \& Yuntawati. (2018). Peningkatan Literasi Matematika Melalui Pembelajaran ELPSA
(Experience, Language, Pictorial, Symbolic, Application). Prosiding Konferensi Nasional Penelitian Matematika Dan Pembelajarannya III (KNPMP III), 24 Maret 2018, Universitas Muhammadiyah Surakarta, Solo, Indonesia, 406-416. Nursahid. (2012). Laporan MGMP Matematika SMP Lombok Barat. Retrieved March 24, 2020, from Forum Komunikasi MGMP Matematika SMP Lombok Barat. http://mgmpmatematikasmpn1kediri. blogspot.com/2012/03/learningjournal.html

Purnomo, E., \& Wijayanto, P. (2018). Efektivitas Model Pelatihan Parenting Autisme Berbasis Media Video. Jurnal Teknologi Pendidikan, 6(1), 92-106.

Retnawati, H. (2015). The Comparison of The Accuracy of Likert Scale. Jurnal Kependidikan: Penelitian Inovasi Pembelajaran, 45(2), 156-167.

Sartika, R. (2017). University Students' Perception on Conflicts in Learning Conflict Resolution Course. Edutech, 16(1), 85-97.

Suarja, Z. A., Fitriati, \& Novita, R. (2017). Pengembangan

Perangkat Pembelajaran Pengembangan Perangkat Pembelajaran Rich Task untuk Meningkatkan Kemampuan Mengajar Matematika untuk Guru Sekolah Menengah Pertama. MAJU: Jurnal Ilmiah Pendidikan Matematika, 4(1), 12-25. http://eproceeding.undiksha.ac.id/ind ex.php/senari/article/view/511

Supriyanto, R. (2019). Profil Peran MGMP Matematika dalam Pengembangan Kompetensi Pedagogik Guru, Motivasi dan Karakter Siswa SMP Negeri di Kota Cirebon. Pediamatika: Journal of Mathematical Science and Mathematics Education, 1(2), 37-46.

Wibawa, C. (2007). Perbedaan Efektifitas Metode Demonstrasi dengan Pemutaran Video tentang Pemberantasan DBD terhadap 
Peningkatan Pengetahuan dan Sikap Anak SD di Kecamatan Wedarijaksa Kabupaten Pati. Jurnal Promosi Kesehatan Indonesia, 2(2), 115-129. Doi: 10.14710/jpki.2.2.115-129.

Zulkifli. (2017). Dampak MGMP Matematika ELPSA dalam Pengembangan Kreativitas Guru pada Pembuatan Media Pembelajaran. Prosiding Seminar ELPSA, IKIP Mataram, Nusa Tenggara Barat, April, 141151. 